\title{
Production of tricarballylic acid by rumen microorganisms and its potential toxicity in ruminant tissue metabolism
}

\author{
BY JAMES B. RUSSELL \\ Agricultural Research Service, USDA and Department of Animal Science, \\ Cornell University, Ithaca, New York 14853, USA \\ AND NEIL FORSBERG \\ Department of Animal Science, Oregon State University, Corvallis, Oregon 97331, USA
}

(Received 25 July 1985-Accepted 16 January 1986)

\begin{abstract}
1. Rumen microorganisms convert trans-aconitate to tricarballylate. The following experiments describe factors affecting the yield of tricarballylate, its absorption from the rumen into blood and its effect on mammalian citric acid cycle activity in vitro.

2. When mixed rumen microorganisms were incubated in vitro with Timothy hay (Phleum pratense L.) and $6.7 \mathrm{~mm}$-trans-aconitate, $64 \%$ of the trans-aconitate was converted to tricarballylate. Chloroform and nirate treatments inhibited methane production and increased the yield of tricarballylate to 82 and $75 \%$ respectively.

3. Sheep given gelatin capsules filled with $20 \mathrm{~g}$ trans-aconitate absorbed tricarballylate and the plasma concentration ranged from 0.3 to $0.5 \mathrm{mM} 9 \mathrm{~h}$ after administration. Feeding an additional $40 \mathrm{~g}$ potassium chloride had little effect on plasma tricarballylate concentrations. Between 9 and $36 \mathrm{~h}$ there was a nearly linear decline in plasma tricarballylate.

4. Tricarballylate was a competitive inhibitor of the enzyme, aconitate hydratase (aconitase; EC 4.2.1.3), and the inhibitor constant, $K_{I}$, was $0.52 \mathrm{~mm}$. This $K_{I}$ value was similar to the Michaelis-Menten constant $\left(K_{m}\right)$ of the enzyme for citrate.

5 . When liver slices from sheep were incubated with increasing concentrations of tricarballylate, $\left[{ }^{14} \mathrm{C}\right]$ acetate oxidation decreased. However, even at relatively high concentrations $(8 \mathrm{~mm})$, oxidation was still greater than $80 \%$ of the maximum. Oxidation of $\left[{ }^{14} \mathrm{C}\right]$ acetate by isolated rat liver cells was inhibited to a greater extent by tricarballylate. Concentrations as low as $0.5 \mathrm{~mm}$ caused a $30 \%$ inhibition of citric acid cycle activity.
\end{abstract}

Grasses, and in particular crested wheat grass (Agropyron desertorum L.), frequently accumulate high concentrations of trans-aconitate which in some cases can account for more than $5 \%$ of the total dry matter (Stout et al. 1967; Kirkby, 1969; Grunes et al. 1970; Barta, 1973; Prior et al. 1973; Bohman et al. 1983b). The observation that high concentrations of trans-aconitate coincided with the occurrence of grass tetany suggested that trans-aconitate could play a role in the grass tetany syndrome (Burau \& Stout, 1965; Stout et al. 1967). Oral administration of trans-aconitate has been shown to increase the incidence of tetany (Bohman et al. 1969), and Grunes (1967) indicated that plant concentrations greater than $1 \%$ may cause tetany.

Kennedy (1968) noted rapid disappearance of trans-aconitate from the rumen and he, as well as other workers (Lomba et al. 1969a, b; Wright \& Wolff, 1969), questioned the importance of this acid in vivo. Recent experiments indicated that trans-aconitate was rapidly fermented by mixed rumen microorganisms, and it seemed unlikely that transaconitate would remain in the rumen long enough to decrease magnesium absorption (Russell \& Van Soest, 1984). High-pressure liquid chromatography of the fermentation products, however, revealed that microbial metabolism of trans-aconitate yielded an unknown compound that was later identified as tricarballylate.

In mixed culture incubations, more than $40 \%$ of the trans-aconitate was converted to tricarballylate, and the conversion was not influenced significantly by the diet given to the donor cow (Russell \& Van Soest, 1984). Enrichment and isolation experiments indicated 


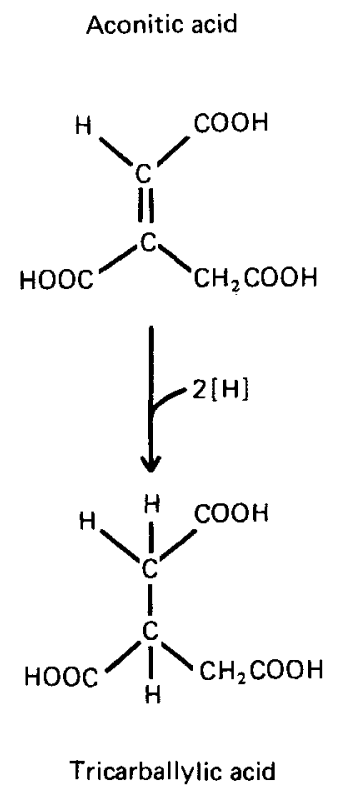

Fig. 1. Structure and likely pathway of aconitic acid conversion to tricarballylic acid (Russell \& Van Soest, 1984).

that the rumen bacterium Selenomonas ruminantium was very active in tricarballylate production (Russell, 1985). Because tricarballylate was fermented slowly, if at all, by mixed rumen bacteria, it could accumulate in the rumen.

Trans-aconitate is converted to tricarballylate by a simple reduction (see Fig. 1) and similar reactions are known to occur in the rumen (Wolin et al. 1961; Baldwin et al. 1965; Paynter \& Elsden, 1970; Hughes \& Tove, 1980). Within the rumen, reducing equivalents are also used in methanogenesis and nitrate reduction (Wolin, 1975), and these reactions might compete with trans-aconitate reduction. Selenomonads are active nitrate reducers (Allison \& Reddy, 1984).

The chemical structure of tricarballylate is similar to that of citrate and the two compounds only differ in a hydrogen/hydroxyl group. Based on this similarity, it seemed possible that tricarballylate could act as a competitive inhibitor of aconitate hydratase (aconitase; EC 4.2.1.3) in the citric acid cycle of animals. Fluorocitrate, an aconitate hydratase inhibitor, causes citrate accumulation, loss of appetite, tetanic convulsions and death (Peters, 1957).

The following series of experiments were designed to: (1) examine the effects of methane inhibition and nitrate on the conversion of trans-aconitate to tricarballylate by mixed cultures of rumen microorganisms, (2) examine the absorption of tricarballylate into blood, (3) examine the effects of tricarballylate on animal metabolism.

In vitro fermentation. Rumen contents were obtained from a non-lactating, rumen-fistulated dairy cow $1.5 \mathrm{~h}$ after feeding. The cow was given Timothy hay (Phleum pratense L.) containing ( $\mathrm{g} / \mathrm{kg}$ dry matter): 670 neutral-detergent fibre, 420 acid-detergent fibre, 94 crude 
protein (nitrogen $\times 6.25$ ), and 64 lignin, as analysed by the methods of Goering \& Van Soest (1970). The contents were squeezed through eight layers of cheese cloth and purged with oxygen-free carbon dioxide. More large feed particles were removed from the rumen fluid by passing it through an additional four layers of cheese cloth. The resulting fluid contained protozoa and a variety of bacteria with differing morphology. Rumen fluid $(20 \%, \mathrm{v} / \mathrm{v})$ was anaerobically transferred to a medium containing (mg/l): $292 \mathrm{~K}_{2} \mathrm{HPO}_{4}, 480\left(\mathrm{NH}_{4}\right)_{2} \mathrm{SO}_{4}$, $480 \mathrm{NaCl}, 100 \mathrm{MgSO}_{4} \cdot 7 \mathrm{H}_{2} \mathrm{O}, 64 \mathrm{CaCl}_{2} \cdot 2 \mathrm{H}_{2} \mathrm{O}, 4000 \mathrm{Na}_{2} \mathrm{CO}_{3}, 600$ cysteine hydrochloride. The rumen fluid in defined medium $(40 \mathrm{ml})$ was anaerobically transferred to serum bottles that contained $0.5 \mathrm{~g}$ Timothy hay (described previously). Methane production was inhibited with $1.0 \mathrm{~mm}$-sodium nitrate or $0.1 \mathrm{~mm}$-chloroform. The trans-aconitate (Sigma Chemical Co., St. Louis, MO) was provided as one dose of $6.7 \mathrm{mM}(1 \times)$ at the beginning of the incubation period or every $3 \mathrm{~h}$ as eight doses $(8 \times)$ of $0.84 \mathrm{~mm}$-aconitate. The bottles were incubated at $39^{\circ}$ for $24 \mathrm{~h}$. The experiment was performed on duplicate days with triplicates per day $(n 6)$.

At the end of the incubation period, $0.5 \mathrm{ml}$ gas was removed from the bottles, and methane and $\mathrm{H}_{2}$ were detected on a Gow Mac series 550 gas-liquid chromatograph (Carbosieve 58100 mesh column; Supelco Co. Inc., Bellefonte, PA). The column temperature was set at $125^{\circ}$ and the detector was $150^{\circ}$. After gas analyses were performed, the bottles were emptied into tubes and centrifuged $\left(10000 \mathrm{~g}, 15 \mathrm{~min}, 0^{\circ}\right)$. Cell-free supernatant fractions were stored at $-15^{\circ}$. Volatile fatty acids, tricarballylate, aconitate, lactate and succinate were measured by high-pressure liquid chromatography (Beckman model 334 liquid chromatograph, model 156 refractive index detector, model 421 CRT data controller, CRIA integrator, Bio Rad HPX-87H organic acid column). The sample size was $50 \mu 1$, the eluant was $0.006 \mathrm{M}$-sulphuric acid and the column temperature was $50^{\circ}$ (Russell \& Van Soest, 1984).

\section{Expt 2}

Absorption. Four cross-bred whether sheep $(77,75,71$ and $48 \mathrm{~kg}$ live weight) were each fitted with a jugular cannula (Abbocath-T16-G $\times 160 \mathrm{~mm}$ Teflon catheter; Abbott Hospitals, Inc, North Chicago, IL 60064). The sheep received Timothy hay (see above) and water ad lib. On the following day, two blood samples $(10 \mathrm{ml})$ were obtained before treatment $(-1$ and $0 \mathrm{~h}$ ). All four sheep then received $20 \mathrm{~g}$ aconitate in gelatin capsules whilst two of the sheep were given an additional $40 \mathrm{~g} \mathrm{KCl}$. Blood samples were taken at 3,6, 12, 18, 24, 30 and $36 \mathrm{~h}$ after treatment. The blood samples were mixed with heparin $(60 \mathrm{USP} / \mathrm{ml})$, centrifuged to remove erythrocytes $\left(1000 \mathrm{~g}, 15 \mathrm{~min}, 0^{\circ}\right)$ and stored at $-15^{\circ}$ until analysed. After $48 \mathrm{~h}$ the experiment was repeated and the sheep were assigned to reverse treatments. Organic acids were measured by high-pressure liquid chromatography (see above) but the high amounts of glucose in blood created an interference to tricarballylate measurement. Increasing the acid content of the eluant to $0.025 \mathrm{M}$ and decreasing the column temperature to $25^{\circ}$ caused the tricarballylate to elute $0.5 \mathrm{~min}$ later and the interference was overcome. Magnesium and calcium were measured by atomic absorption spectrophotometry (PerkinElmer, 1982), and deproteinized samples were analysed for glucose by an enzymic method (Bergmeyer \& Klotsch, 1965).

A Tukey's test was used to determine statistical differences among the means of fermentation products. Gill (1973) indicated that this test is valid when one must resort to comparing all possible pairs of means.

\section{Expt 3}

Citric acid cycle inhibition. Aconitate hydratase (Sigma Chemical Co.) was assayed by a method employing isocitrate dehydrogenase $\left(\mathrm{NADP}^{+}\right)(E C 1.1 .1 .42)$ and the formation 
of NADPH was followed at $340 \mathrm{~nm}$ (Sigma Chemical Co., 1977). The reaction mixture contained $0.3 \mathrm{mg} \mathrm{MnSO}_{4} \cdot \mathrm{H}_{2} \mathrm{O}, 0.15 \mathrm{mg}$ NADP, $0.25 \mathrm{IU}$ isocitrate dehydrogenase $\left(\mathrm{NADP}^{+}\right)$0.015 IU aconitate hydratase (activated by the method of Morrison, 1954) and less than $2.0 \mu \mathrm{mol}$ citrate $/ \mathrm{ml}$ Tris buffer $(0.1 \mathrm{M}, \mathrm{pH} 7 \cdot 4)$. Aconitate hydratase inhibition was monitored by adding $2.0 \mu \mathrm{mol}$ tricarballylate $/ \mathrm{ml}$, and a Lineweaver-Burk plot of the values was constructed.

Two mixed-breed sheep (50 and $65 \mathrm{~kg}$ ), maintained on lucerne (Medicago sativa)-hay diets, were killed by electric shock and exsanguination. A portion of the caudate lobe of the liver was excised, placed in Krebs-Henseleit bicarbonate (KHB) medium (Seglen, 1976) and transported to the laboratory. Slices ( $100 \mathrm{mg}, 0.5 \mathrm{~mm}$ thickness) of liver were incubated for $1 \mathrm{~h}$ at $39^{\circ}$ in $3 \mathrm{ml} \mathrm{KHB}$ media $(0.5$ recommended $\mathrm{Ca})$ in $25 \mathrm{ml}$ Erlenmeyer flasks. The media had previously been equilibrated with $\mathrm{O}_{2}-\mathrm{CO}_{2}(95: 5, \mathrm{v} / \mathrm{v})$ gas mixture to maintain a $\mathrm{pH}$ of $7 \cdot 4$. The media contained bovine serum albumin (BSA; $2.5 \mathrm{~g} / \mathrm{l}$ ), $2.5 \mathrm{~mm}$-sodium acetate, $0.25 \mu \mathrm{Ci}\left[1^{-14} \mathrm{C}\right]$ acetate (Amersham Corp., Arlington, Illinois) and 0, 0.5, 1, 2, 4 or $8 \mathrm{~mm}$-sodium tricarballylate. All treatments of tricarballylate were performed in triplicate. Incubations were terminated by injection of $1 \mathrm{ml} 1 \mathrm{M}-\mathrm{H}_{2} \mathrm{SO}_{4}$ through the serum stopper. Evolved ${ }^{14} \mathrm{CO}_{2}$ was collected with hyamine hydroxide (New England Nuclear). Total ${ }^{14} \mathrm{C}$ activity associated with the hyamine hydroxide was determined by solubilizing in ACS scintillation cocktail (Amersham Corp.) and subsequent liquid scintillation counting.

Rat hepatocytes were prepared from a $200 \mathrm{~g}$ male CD rat according to the methods of Seglen (1976). The entire liver was dissected and perfused with $\mathrm{Ca}$-free free $\mathrm{KHB}$ with

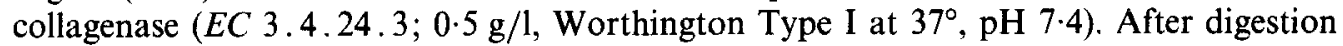
of non-parenchymal tissue, the liver cells were filtered through a $286 \mu \mathrm{m}$-polyethylene mesh and resuspended in KHB ( 0.5 recommended $\mathrm{Ca})$. Cells were centrifuged $(50 \mathrm{~g}, 3 \mathrm{~min})$ and resuspended in this medium three times. The final concentration of cells was $118 \mathrm{mg} / \mathrm{ml}$. The cell suspension $(1 \mathrm{ml})$ was subsequently pipetted into $25-\mathrm{ml}$ Erlenmeyer flasks containing $3 \mathrm{ml} \mathrm{KHB}\left(\mathrm{pH} 7 \cdot 5, \mathrm{O}_{2}-\mathrm{CO}_{2}(95: 5, \mathrm{v} / \mathrm{v})\right.$ and $0.25 \mu \mathrm{Ci}\left[1-{ }^{14} \mathrm{C}\right]$ acetate). Final concentrations of acetate and BSA in media were $2.375 \mathrm{~mm}$ and $2.5 \mathrm{~g} / 1$ respectively. Tricarballylate was added at $0,0.5,1,2,4$ or $8 \mathrm{~mm}$ and incubations were performed for $0.5 \mathrm{~h}$. Collection of $\mathrm{CO}_{2}$, liquid scintillation counting, and control flasks were as described for sheep slices. Viability of the liver cells was determined from lactic acid dehydrogenase (EC 1.1.1.27) activity.

\section{RESULTS}

\section{Expt 1}

In vitro fermentation. When Timothy hay was incubated for $24 \mathrm{~h}$ with mixed rumen microorganisms in vitro, the ratio, acetate:propionate: butyrate production was $5 \cdot 8: 2 \cdot 6: 1$, nearly $7 \mathrm{mmol}$ methane/1 medium were produced, and there were either trace or nondetectable concentrations of trans-aconitate, tricarballylate, $\mathrm{H}_{2}$, formate, lactate and succinate (Table 1). Addition of $0.1 \mathrm{~mm}$-chloroform completely eliminated methane production and there was a significant increase in $\mathrm{H}_{2}$ and formate production $(P<0.05)$. Acetate formed was two-thirds that of the control, but this trend was not statistically significant $(P>0.05)$. Nitrate suppressed but did not completely inhibit methane production, and only a small increase in $\mathrm{H}_{2}$ and formate production was noticed. A combination of chloroform and nitrate eliminated methane, increased $\mathrm{H}_{2}$ and formate, and decreased propionate $(P<0.05)$.

Approximately $64 \%$ of the added aconitate was converted to tricarballylate, and this conversion was the same whether the acid was added once $(1 \times)$ or eight times $(8 \times)$ during the incubation period (Table 1). Inhibition of methane production by chloroform and 
Tricarballylic acid

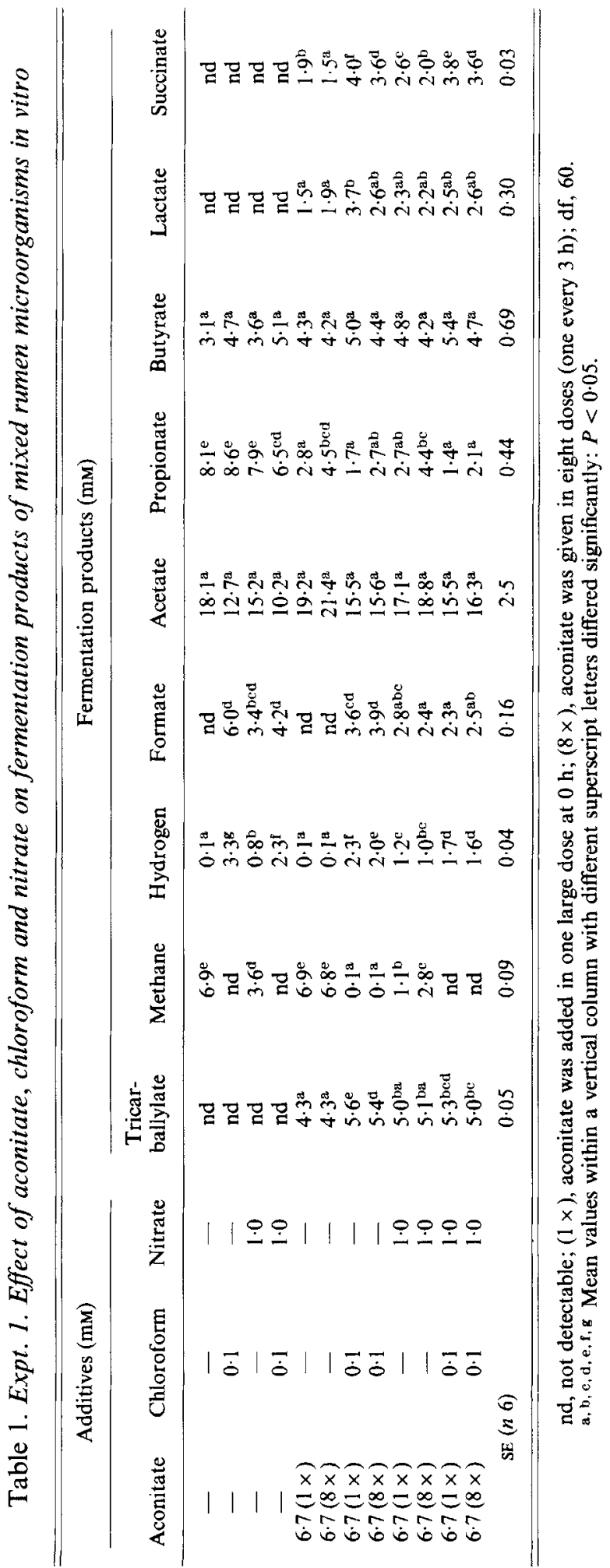




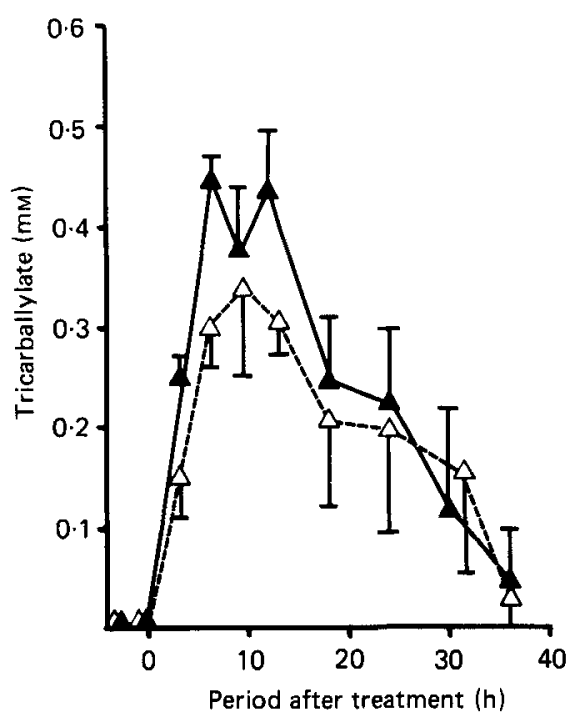

Fig. 2. Expt 2. Concentration of tricarballylate in the blood of sheep given trans-aconitate. Each sheep was given $20 \mathrm{~g}$ aconitate $(\Delta)$ or $20 \mathrm{~g}$ aconitate plust $40 \mathrm{~g}$ potassium chloride $(\Delta)$ at $0 \mathrm{~h}$. Points are mean values with standard errors represented by vertical bars (df 2 ).

nitrate increased the yield of tricarballylate to 82 and $75 \%$ of added aconitate respectively. Aconitate by itself did not cause a decrease in methane but the combination of aconitate plus nitrate showed less methane than nitrate alone $(P<0.05)$. Aconitate fermentation caused a decrease in propionate and an appearance of lactate and succinate $(P<0.05)$.

\section{Expt 2}

Absorption. After cannulated sheep were force-fed gelatin capsules containing $20 \mathrm{~g}$ aconitate at $t=0 \mathrm{~h}$, tricarballylate was detected in the plasma (Fig. 2). Whilst sheep given $\mathrm{KCl}$ as well as aconitate accumulated somewhat more tricarballylate than sheep given only aconitate, these differences were not significant $(P>0.05)$. By $9 \mathrm{~h}$ after tricarballylate treatment both groups of sheep had more than $0.33 \mathrm{~mm}$-tricarballylate in plasma. From 9 to $36 \mathrm{~h}$ there was a nearly linear decrease in plasma tricarballylate. Aconitate could not be detected in plasma from any of the sheep after this time. There was no statistically significant change $(P>0.05)$ in the average concentration of lactate $(84.1$ (SE $(34.7) \mathrm{mg} / \mathrm{l})$, glucose $(643$ (SE 51.5) mg/l), Mg (20.8 (SE 1.6) mg/l) or Ca (90.8 (SE 4.4) mg/l) during the $36 \mathrm{~h}$.

\section{Expt 3}

Citric acid cycle inhibition. Addition of tricarballylate caused a decrease in aconitate hydratase activity and the decrease was most dramatic at low concentrations of citrate. A Lineweaver-Burk transformation of the kinetics indicated that tricarballylate was a competitive inhibitor of aconitate hydratase (Fig. 3). The intercept of the ordinate, an indicator of maximum velocity $\left(V_{\max }\right)$, was unchanged, but there was an increase in the apparent Michaelis-Menten constant $\left(K_{m}\right)$ of enzyme for substrate. Assuming that the increase in slope $\left(K_{m} / V_{\max }\right)$ was proportional to $\left(1+\mathrm{I} / K_{I}\right) K_{m} / V_{\max }$, the inhibitor constant, $K_{I}$, was $0.52 \mathrm{~mm}$. This value of $K_{I}$ approximated the $K_{m}, 0.30 \mathrm{~mm}$.

When liver slices from sheep were incubated with increasing concentrations of tricarballylate, there was a decrease in $\left[{ }^{14} \mathrm{C}\right]$ acetate oxidation. However, even at relatively high 


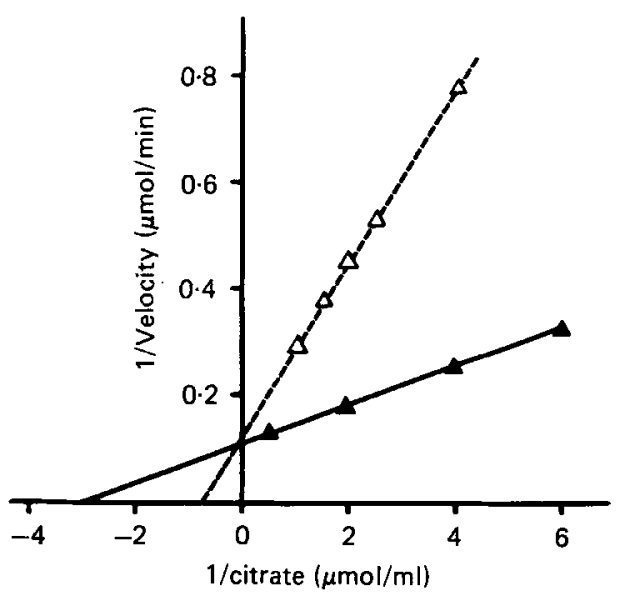

Fig. 3. Expt 3. A Lineweaver-Burk plot of $1 /$ citrate $v .1 /$ velocity with $(\Delta)$ and without (A) $2 \mu \mathrm{mol}$ tricarballylate $/ \mathrm{ml}$.
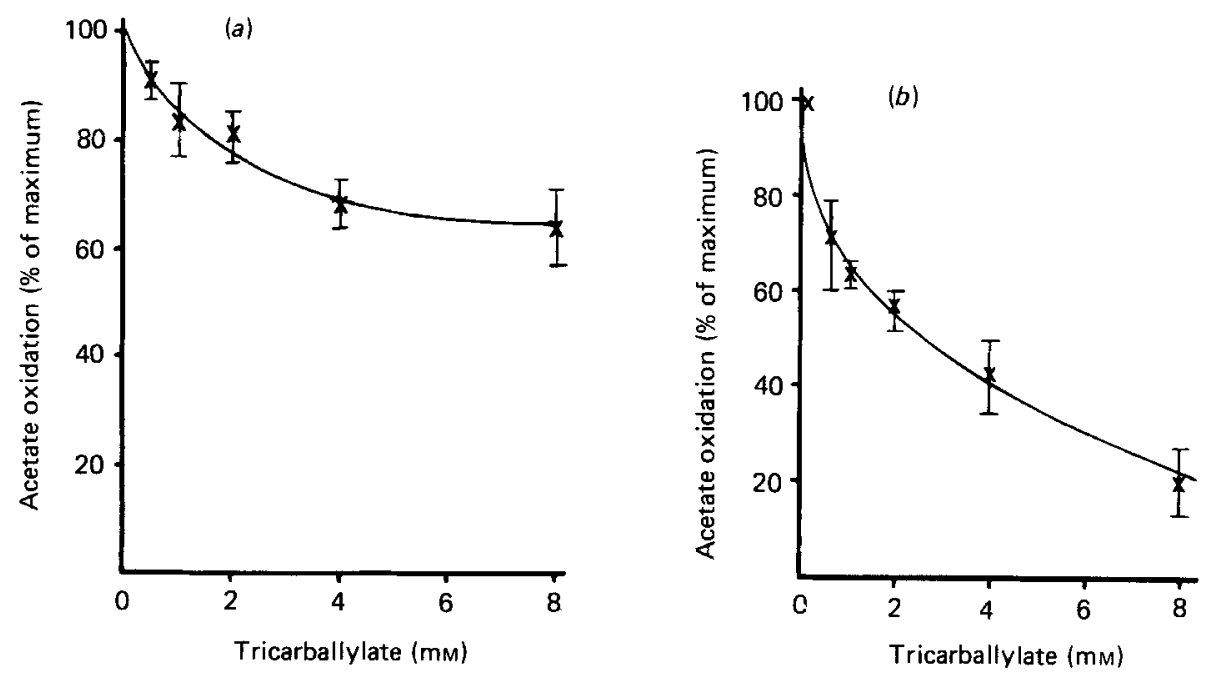

Fig. 4. The effect of tricarballylate on the oxidation of $\left[{ }^{14} \mathrm{C}\right]$ acetate $(\mathrm{df} 2)$ by $(a)$ liver slices from sheep and $(b)$ isolated rat hepatocytes. Points are mean values with standard errors represented by vertical bars.

concentrations ( $8 \mathrm{~mm})$, oxidation was still greater than $80 \%$ of maximum. At concentrations approximating those observed in blood (Fig. 2), the inhibition was nominal (Fig. 4(a)). When isolated liver cells from rats were incubated with tricarballylate, the inhibition of acetate oxidation was greater (Fig. $4(b)$ ). With $8 \mathrm{~mm}$-tricarballylate, oxidation was inhibited by $75 \%$ and concentrations as low as $0.5 \mathrm{~mm}$ caused a $30 \%$ inhibition.

\section{DISCUSSION}

When aconitate was added to in vitro incubations containing Timothy hay and mixed rumen microorganisms, $64 \%$ of the aconitate was converted to tricarballylate (Table 1 ). In previous 
experiments, the conversion was only $40 \%$, but these incubations did not contain added carbohydrate (Russell \& Van Soest, 1984). Enrichment and isolation studies showed that the reduction of aconitate to tricarballylate was dependent on the supply of reducing equivalents from carbohydrate fermentation (Russell, 1985). In these experiments, the conversion of added aconitate was similar if acid was provided once $(1 \times)$ or eight times $(8 \times)$. These results indicated that aconitate-reducing organisms were active throughout the incubation with Timothy hay. The use of chloroform, a potent methane inhibitor, diverted reducing equivalents away from methanogenesis and increased the production of tricarballylate.

Nitrate reduction represents a competing mechanism of reducing-equivalent disposal, and on this basis one would have expected an inverse relation between nitrate and tricarballylate formation. Nitrate, however, exerts an overriding decrease on methane production (Allison \& Reddy, 1984). By decreasing the production of methane, nitrate treatment increased tricarballylate (Table 1). Rather high concentrations of nitrate were used in the experiments $(10 \mathrm{~mm})$ but the interaction between nitrate and tricarballylate could have practical significance. Wheat pastures causing a $16 \%$ incidence of grass tetany had between 15 and $84 \mathrm{mmol}$ nitrate $/ \mathrm{kg}$ (Bohman et al. 1983a).

Lactate and succinate were not detected in control incubations, but aconitate treatment effected a small increase in these acids (Table 1). Accumulations of lactate and succinate are not easily explained. Succinate rarely, if ever, accumulates in the rumen (Wolin, 1975), so we attempted to validate our identification of succinate further. Pyruvate, lactate, malate, fumarate and oxaloacetate had retention times during high-pressure liquid chromatography that differed significantly (greater than $1 \mathrm{~min}$ ) from succinate. A methylated derivative of the unknown acid had the same retention time as methylated succinate when they were analysed by gas-liquid chromatography. Selenomonas ruminantium was the most active aconitate reducer isolated from rumen fluid (Russell, 1985), and it can either utilize or produce lactate and succinate (Bryant, 1956; Scheifinger \& Wolin, 1973; Wolin, 1975; Chen \& Wolin, 1977; Linehan et al. 1978). One possibility is that aconitate competes with succinate or lactate in the uptake systems of Selenomonas ruminantium.

In vivo experiments with sheep given $20 \mathrm{~g}$ aconitate indicated that tricarballylate was absorbed into the blood and, at $9 \mathrm{~h}$ after feeding, tricarballylate concentrations ranged from 0.3 to $0.5 \mathrm{~mm}$ (Fig. 2). Since plants contain as much as $5 \%$ aconitate (Burau \& Stout, 1965; Stout et al. 1967), $20 \mathrm{~g}$ of aconitate was not a particularly high dose. Assuming normal dose relations, tricarballylate concentrations could exceed those reported here. Scotto et al. (1971) noted a positive relation between dietary $\mathrm{KCl}$ treatment and citrate absorption, but we did not observe a significant effect of $\mathrm{KCl}$ on tricarballylate absorption. Citrate is rapidly fermented by rumen microorganisms (Wright, 1971; Russell \& Van Soest, 1984); however, $\mathrm{KCl}$ may have increased rumen fluid dilution rate and washed citrate out of the rumen before it could be fermented. During the experimental period, sheep given $\mathrm{KCl}$ consumed twice as much water but aconitate was never detected in the blood. These results indicated that nearly all of the aconitate was fermented to tricarballylate even in the presence of $\mathrm{KCl}$.

Blood concentrations of tricarballylate remained elevated for approximately $36 \mathrm{~h}$ after aconitic acid treatment (Fig. 2). These results are consistent with the hypothesis that tricarballylate is not metabolized by animal tissues. The structure of tricarballylate is similar to citrate and enzyme studies indicated that tricarballylate was a competitive inhibitor of the enzyme aconitate hydratase (Fig. 3). The $K_{I}$ of tricarballylate was $0.52 \mathrm{~mm}$; fluorocitrate had a $K_{I}$ of $0.20 \mathrm{~mm}$ (Peters \& Wilson, 1952). The $K_{I}$ of tricarballylate was similar to the $K_{m}$ for citrate (Fig. 3), and this similarity meant that tricarballylate could exert a physiological effect in vivo. Morrison (1954) reported a $K_{m}$ of $3.6 \mathrm{~mm}$; however, the product, isocitrate, was not removed during the assay. Isocitrate was removed by isocitrate 
dehydrogenase $\left(\mathrm{NADP}^{+}\right)$in the experiments of Peters \& Wilson (1952) and their value of $0.46 \mathrm{~mm}$ was close to ours.

In vitro experiments with tissue liver slices from sheep indicated that tricarballylate was indeed a citric acid cycle inhibitor, but the results may have been distorted by differential rates of $\left[{ }^{14} \mathrm{C}\right]$ acetate and tricarballylate entry. The metabolic activity of mammalian tissue declines rapidly when the blood supply is removed, and in vitro slice experiments are usually conducted over relatively short periods of time (e.g. -0.5 to $1.0 \mathrm{~h}$ ). The slices are several cells thick and metabolites in the medium must either diffuse in or be actively transported by the tissue. Acetate is a more lipophilic molecule and is readily translocated across the cell membrane. Tricarballylate is a very polar molecule and would not diffuse across the membrane as easily. When isolated liver cells from rats were incubated with tricarballylate, the degree of inhibition was greater. Since the isolated cells were not located in a tissue bed several layers thick, the surface area for tricarballylate and acetate uptake was greater. Under these conditions any bias caused by differential rates of entry would have been lessened. Preparation of isolated sheep cells was confounded by practical and theoretical considerations.

Bohman et al. (1983a) noted that sheep grazing wheat pasture and showing symptoms of grass tetany had high levels of plasma glucose and lactate. These observations are consistent with the supposition that tricarballylate inhibits citric acid cycle activity. When the citric acid cycle is inhibited the tissue switches to an anaerobic metabolism characterized by lactate production. Our blood samples, however, did not show significant increases in glucose or lactate during the period of tricarballylate accumulation.

Grass tetany symptoms are accentuated by a variety of physiological factors including a deficiency of dietary $\mathrm{Mg}$, a demand for $\mathrm{Mg}$ in lactation, an imbalance of dietary carbohydrate and $\mathrm{N}$, and high intakes of water, $\mathrm{K}$ and organic acids (Mayland \& Grunes, 1979). We attempted to mimic some factors (e.g. aconitic acid and K) but other aspects were not the same. Our non-lactating sheep were not deficient in $\mathrm{Mg}$ and they did not show visible or clinical symptoms of grass tetany. These experiments, however, did establish four factors: (1) aconitate is reduced to tricarballylate by rumen microorganisms in vivo, (2) tricarballylate is absorbed into blood in significant quantities, (3) tricarballylate is a competitive inhibitor of the enzyme aconitate hydratase, (4) tricarballylate inhibits acetate oxidation by the citric acid cycle of animals in vitro. The aetiology of grass tetany is probably complicated by a variety of interacting variables. Further work is needed to characterize and evaluate the importance of tricarballylate as one of these variables.

This research was supported by the United States Dairy Forage Research Center, Madison, Wisconsin. The authors would like to express appreciation to H. F. Mayland, D. L. Grunes and W. A. Norvell for valuable comments that were incorporated into the final draft of this manuscript.

\section{REFERENCES}

Allison, M. J. \& Reddy, C. A. (1984). In Current Perspectives in Microbial Ecology, pp. 248-256 [M. J. Klug and C. A. Reddy, editors]. Washington, DC: American Society for Microbiology.

Baldwin, R. L., Wood, W. A. \& Emery, R. S. (1965). Biochimica et Biophysica Acta 97, 202-213.

Barta, A. L. (1973). Crop Science 13, 113-114.

Bergmeyer, H. U. \& Klotsch, H. (1965). In Methods of Enzymatic Analysis, pp. 99-102 [H. U. Bergmeyer, editor]. New York: Academic Press.

Bohman, V. R., Horn, F. P., Littledike, E. T., Hurst, J. G. \& Griffen, D. (1983a). Journal of Animal Science 57, 13641373.

Bohman, V. R., Horn, F. P., Stewart, B. A., Mathers, A. C. \& Grunes, D. L. (1983b). Journal of Animal Science 57, 1352-1363.

Bohman, V. R., Lesperance, A. L., Harding, G. D. \& Grunes, D. L. (1969). Journal of Animal Science 29, $99-102$. 
Bryant, M. P. (1956). Journal of Bacteriology 72, 162-167.

Burau, R. G. \& Stout, P. R. (1965). Science 150, 766-767.

Chen, M. \& Wolin, M. J. (1977). Applied Environmental Microbiology 34, 756-759.

Gill, J. L. (1973). Journal of Dairy Science 56, 973-977.

Goering, H. K. \& Van Soest, P. J. (1970). Forage Fiber Analysis, US Department of Agriculture Handbook no. 379. Washington, DC: US Department of Agriculture.

Grunes, D. L. (1967). Cornell Nutrition Conference for Feed Manufacturers. Buffalo N.Y. p. 105. Ithaca, NY: Cornell Agricultural Experiment Station.

Grunes, D. L., Stout, P. R. \& Brownell, J. R. (1970). Advances in Agronomy 22, 331-374.

Hughes, P. E. \& Tove, S. B. (1980). Journal of Biological Chemistry 255, 4447-4452.

Kennedy, G. S. (1968). Australian Journal of Biological Sciences 21, 529-538.

Kirkby, E. A. (1969). In Ecological Aspects of the Mineral Nutrition of Plants, pp. 215-235 [1. H. Rorison, editor]. Oxford: Blackwell Scientific Publishers.

Linehan, B., Scheifinger, C. C. \& Wolin, M. J. (1978). Applied Environmental Microbiology 35, 317-322.

Lomba, F., Fumiere, I., Chauvaux, G., Binot, H. \& Bienfet, V. (1969a). Annales de Medicine et Veterinare 113, 22-23.

Lomba, F., Fumiere, I., Chauvaux, G., Binot, H. \& Bienfet, V. (1969b). Annales de Medicine et Veterinare 113, 90-100.

Mayland, H. F. \& Grunes, D. L. (1979). In Grass Tetany, pp. 123-175 [V. V. Rendig and D. L. Grunes, editors]. Madison, Wisconsin: American Society of Agronomy.

Morrison, J. F. (1954). Australian Journal of Experimental Biology 32, 867-876.

Paynter, M. J. B. \& Elsden, S. R. (1970). Journal of General Microbiology 61, 1-7.

Perkin-Elmer (1982). Analytical Methods for Atomic Absorption Spectrophotometry. Norwalk, Conn.: Perkin-Elmer.

Peters, R. A. (1957). Advances in Enzymology 18, 113-119.

Peters, R. A. \& Wilson, T. H. (1952). Biochimica et Biophysica Acta 9, 310-315.

Prior, R. L., Grunes, D. L., Patterson, R. P., Smith, F. W., Mayland, H. F. \& Visek, W. J. (1973). Journal of Agricultural and Food Chemistry 21, 73-77.

Russell, J. B. (1985). Applied Environmental Microbiology 49, 120-126.

Russell, J. B. \& Van Soest, P. J. (1984). Applied Environmental Microbiology 47, 155-159.

Scheifinger, C. C. \& Wolin, M. J. (1973). Applied Microbiology 26, 789-795.

Scotto, K. C., Bohman, V. R. \& Lesperance, A. L. (1971). Journal of Animal Science 32, 354-358.

Seglen, P. O. (1976). In Methods in Cell Biology, vol. 13, pp. 29-83 [D. M. Prescott, editor]. New York: Academic Press.

Sigma Chemical Co. (1977). Aconitase Methodology Sheet A-5384. St Louis, MO: Sigma Chemical Co.

Stout, P. R., Brownell, J. R. \& Bureau, R. G. (1967). Agronomy Journal 59, $21-24$.

Wolin, M. J. (1975). In Digestion and Metabolism in the Ruminant, pp. 134-148 [I. W. McDonald \& A. C. L. Warner, editors]. Armidale, NSW, Australia: University of New England Publishing Unit.

Wolin, M. J., Wolin, E. A. \& Jacobs, N. J. (1961). Journal of Bacteriology 8, 911-917.

Wright, D. E. (1971). Applied Microbiology 21, 165-168.

Wright, D. E. \& Wolff, J. E. (1969). New Zealand Journal of Agricultural Research 12, 287-292. 